UDC 377.031 .4

\title{
The use of personally-oriented educational technologies in the formation of mathematical competences
}

\author{
Tumanova N. * \\ Svitlovodsk Polytechnic College of the Central National Technical University, Svitlovodsk, Ukraine
}

Received: $10.03 .2019 \quad$ Accepted: 28.12 .2019

\begin{abstract}
The training of graduates of a higher educational institution of the second level must comply with the established requirements of the educational and professional degree of a junior bachelor. They must possess the indicated qualities, which is the rationale for the development and application of new educational technologies in the educational process. The essence of the formation of mathematical competencies is highlighted. The main tasks and directions of their implementation in the study of mathematics in higher education institutions of the second level of accreditation are established. Mathematical competencies were selected, which should be provided with modern pedagogical technologies in accordance with the Concept of the new Ukrainian school. The types of pedagogical teaching technologies that can be used to form the basic mathematical competencies are considered. The indicated advantages and disadvantages that arise as a result of their application. Methods are formed to develop the mental abilities of students. Based on the results of the analysis of research by leading experts in the field of pedagogy, the criteria for the acquisition of mathematical competence for students of the second level higher education institution are determined. To obtain certain competencies, pedagogical technology is applied that is focused more on the student, and not on the subject of study, on the verification of the practice (teaching methods and techniques) in the course of empirical analysis and the widespread use of audiovisual means in teaching, defines the practice in close connection with the theory of instruction. A personality-oriented approach combines upbringing and education in a single process of assistance, support, development of a student, preparing him for life creativity and the like.

Key words: mathematical competencies, teaching technologies, educational technologies, problem-based learning.
\end{abstract}

\section{Використання особистісно-орієнтованих освітніх технологій у формуванні математичних компетенцій}

Туманова Н. П.

Світловодський політехнічний колеж Центральноукраїнського національного технічного університету, Світловодськ, Україна

Анотація. Підготовка випускники вищого навчального закладу другого рівня повинна відповідати встановленим вимогам щодо освітньо-професійного ступеня молодшого бакалавра, які повинні володіти вказаними якостями, що є обірунтуванням щодо розвитку та застосуванням новітніх освітніх технологій у навчальному процесі. Висвітлено суть формування математичних компетентностей, основні завдання та напрямки ї реалізації при вивченні математики у вищих навчальних закладах другого рівня акредитації. Розглянуто математичні компетентності які мають бути забезпеченими сучасними педтехнологіями відповідно до Концепції нової української школи. Розглянуто види педагогічних технологій навчання, які можна використати для формування основних математичних компетентностей. Вказані переваги та недоліки, які виникають в результаті їх застосування. Сфоормовано методи розвивати розумові здібності студентів. За результатами проведеного аналізу досліджень провідних фрахівців у області педагогіки визначені критерії набуття математичної компетентності для студентів вищого навчального закладу другого рівня. Для отримання визначених компетентносте застосовують педагогічну технологію що орієнтована в більшій мірі на учня, а не на предмет вивчення, на перевірку виробленої практики (методів і техніки навчання) в ході емпіричного аналізу й широкого використання аудіовізуальних засобів у навчанні, визначає практику в тісному зв'язку з теорією навчання. Особистісно-орієнтований підхід поєднує виховання та освіту в єдиний процес

\footnotetext{
Corresponding Author: Tumanova Nataliia Pavlivna, E-mail: natalaiya.tumanova.76@mail.com Svitlovodsk Polytechnic College of the Central National Technical University, vul. Horodotska, 15, Svitlovodsk, Ukraine, 27501.

Відповідальний автор: Туманова Наталія Павлівна. E-mail: natalaiya.tumanova.76@mail.com Світловодський політехнічний коледж Центральноукраїнського національного технічного університету. вул. Городоцька, 15, м. Світловодськ, Україна, 27501.
} 
допомоги, підтримки, соціально-педагогічного захисту, розвитку студента, підготовки його до життєвої творчості тощо.

Ключові слова: математичні компетентності, технології навчання, освітні технології, проблемне навчання.

\title{
Использование личностно-ориентированных образовательных технологий в формировании математических компетенций
}

\author{
Туманова Н. П.
}

Светловодский политехнический колледж Центрально национального технического университета, Светловодск, Украина

\begin{abstract}
Аннотация. Подготовка выпускников высшего учебного заведения второго уровня должна соответствовать установленным требованиям образовательно-профессиональной степени младшего бакалавра, которые должны обладать указанными качествами, является обоснованием для развитию и применением новейших образовательных технологий в учебном процессе. Освещена суть формирования математических компетентностей, основные задачи и направления их реализации при изучении математики в высших учебных заведениях второго уровня аккредитации. Рассмотрены математические компетентности, которые должны быть обеспечены современными педагогическими технологиями в соответствии с Концепцией новой украинской школы. Рассмотрены виды педагогических технологий обучения, которые можно использовать для формирования основных математических компетенций. Указанные преимущества и недостатки, которые возникают в результате их применения. Сформированы методы развивать умственные способности студентов. По результатам проведенного анализа исследований ведущих специалистов в области педагогики определены критерии приобретения математической компетентности для студентов высшего учебного заведения второго уровня. Для получения определенных компетентностей применяют педагогическую технологию ориентированной в большей степени на ученика, а не на предмет изучения, на поверку произведенной практики (методов и техники обучения) в ходе эмпирического анализа и широкого использования аудиовизуальных средств в обучении, определяет практику в тесной связи теории обучения. Личностно ориентированный подход сочетает воспитание и образование в единый процесс помощи, поддержки, социально-педагогической защиты, развития студента, подготовки его к жизненной творчества и тому подобное.
\end{abstract}

Ключевые слова: математические компетентности, технологии обучения, образовательные технологии, проблемное обучение.

\section{Bcmyn}

Підготовка випускники ВНЗ другого рівня повинна відповідати вимогам щодо освітньопрофесійного ступеня молодшого бакалавра, щоб мати можливість реалізувати отримані навички і вміння у своїй трудовій діяльності з відповідним матеріальним забезпеченням. Отже випускники коледжу повинні володіти певними якостями (рис. 1).

Зважаючи на те, що компетентність - це результат когнітивного розвитку, а французький психолог Ж. Піаже каже, що когнітивні здібності ми повинні самостійно конструювати через свої власні дії в навколишньому середовищі, перед викладачем стоїть головне завдання - розвивати розумові здібності студентів. Їхнє формування має бути не стихійним, а цілеспрямованим, поетапним і систематичним. Останнє можливе за умови планування й управління розвитком особистості. Питання управління навчальною діяльністю розкрито в роботах Т. Шамової, Т. Давиденко. У роботах вказаних учених розглянуто:

- психологічні моделі процесу творчості, якості творчої особистості та творчих здібностей;

* психологічний механізм творчості;

* виявлення творчих здібностей;

* методи пошуку творчих розв'язків;

* алгоритми розв'язання проблемних ситуацій, різні форми сумісної діяльності викладачів і учнів, різні підходи до управління розвитку особистості [1].

Компетентності як інтегрований результат навчально-виховної діяльності студентів формуються передусім на основі опанування багатокомпонентного змісту загальної освіти шляхом реалізації відповідних педагогічних технологій. Тому сучасні педтехнології мають забезпечити формування зокрема таких компетентностей: 
* соціальних, пов'язаних із формуванням цінностей демократичного суспільства, громадянських якостей особистості;

* комунікативних;

* інформаційних, передбачає оволодіння вміннями здобувати різноманітну інфрормацію, осмислювати та використовувати іï;;

* полікультурних, стосуються розуміння несхожості людей, поваги до їхньої мови, релігії, культури;

* саморозвитку та самоосвіти, пов'язані із потребою та готовністю постійно навчатися, виконувати творчі завдання.

Відповідно до Концепції нової української школи, математична компетентність належить до 10 ключових компетентностей [2].

Здатності потрібні для формування математичних компетентностей наведені на рис. 1. Набуття математичних компетентностей $є$ одним із головних завдань при вивченні математики в коледжі, їх наявність впливає на якість знань і 3 інших предметів природничого циклу. Критерії набуття математичної компетентності згідно з [2] наведені на рис. 2.

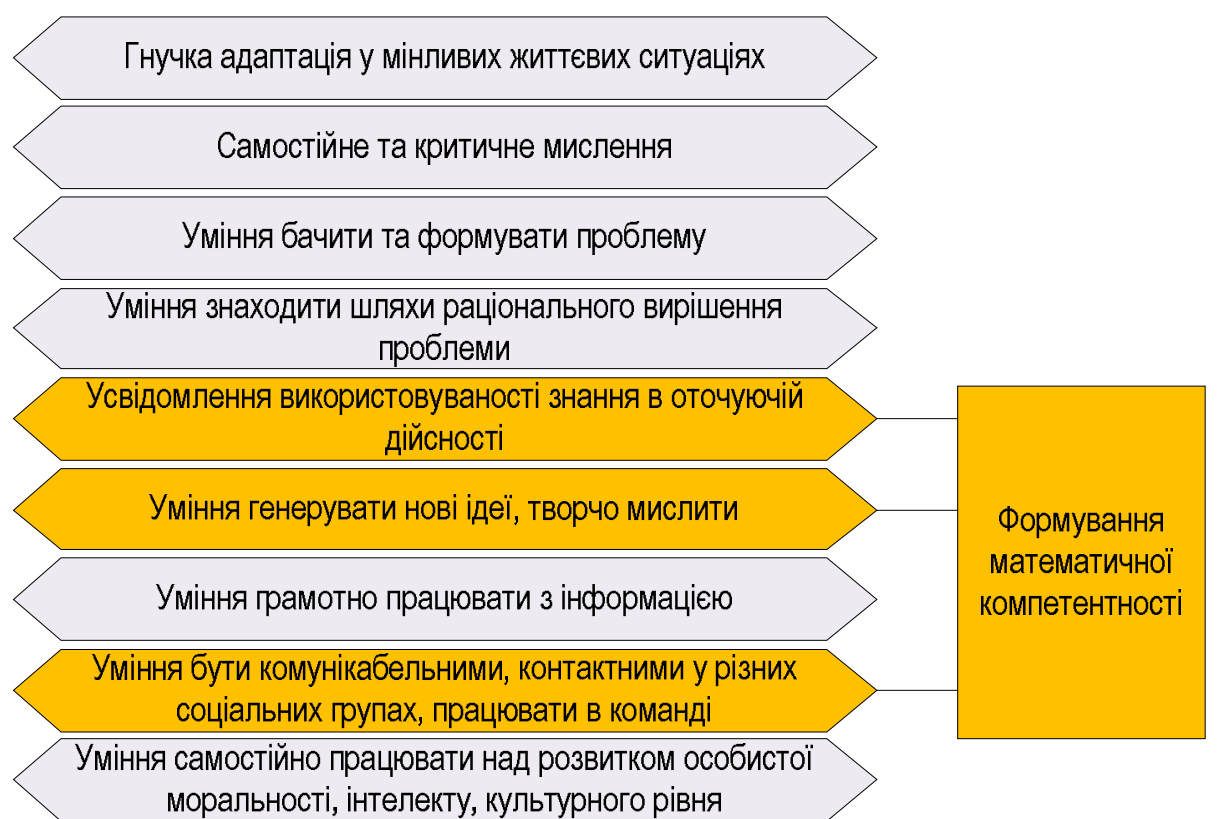

Рис. 1. Якості, здібності та уміння випускників коледжу

Уміння будувати і досліджувати математичні моделі реальних об`єктів, процесів і явищ

Уміння володіти необхідною інформацією для розуміння постановки математичного завдання

Уміння володіти технікою ручних та інструментальних обчислень

Уміння здійснювати алгоритмічну та евристичну діяльність на математичному матеріалі

Уміння працювати з формулами

Уміння будувати і читати графіки функціональних залежностей, досліджувати їх властивості

Уміння класифікувати і конструювати геометричні фігури на площині і у просторі

Уміння оцінювати шанси настання тих чи інших подій, міру ризику під час того чи іншого рішення, обирати оптимальний варіант

Рис. 2. Критерії набуття математичної компетентності 
За час навчання студент стикаються з рядом проблем щодо до вивчення навчальних дисциплін. Суттєві проблеми виникають у студентів першого курсу навчання під час оволодіння навчальними дисциплінами математичного напрямку. Математика - один із складних предметів освітнього простору, i формування математичних компетентностей у студентів набуває певних утруднень. Викладач повинен допомогти студенту подолати труднощі при засвоєнні матеріалу. Тому викладач виступає в ролі організатора, компетентного консультанта і помічника.

Метою роботи $є$ розвиток і покращення методики викладання навчальних дисциплін математичного спрямування.

\section{II Матеріал і методи дослідження}

Проблема розвитку методик викладання навчальних дисциплін математичного спрямовання залишається досі актуальною.

Для вирішення цієї проблеми можна використовувати освітні технології. Поняття «освітня технологія», «педагогічна технологія», «технологія навчання» широко використовуються у педагогічній практиці, але мають багато формулювань в залежності від структури і компонент освітнього процесу, на яких вони базуються [3]. Аспекти, в яких вживається поняття «технологія» наведені на рис. 2.

Педагогічна технологія - за визначенням ЮНЕСКО, це в загальному розумінні системний метод створення, застосування й визначення всього процесу навчання і засвоєння знань, з урахуванням технічних і людських ресурсів та їх взаємодії, який ставить своїм завданням оптимізацію освіти [5]. Педагогічна технологія більше орієнтована на учня, а не на перевірку методик і технік навчання, застосовується у тісному зв'язку практики 3 теорією, ґрунтується на широкому застосуванні аудіовізуальних засобів у навчанні.
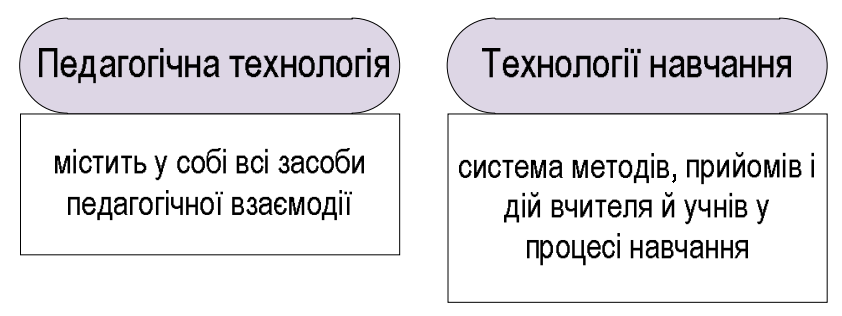

\section{Рис. 2. Аспекти поняття «технологія»}

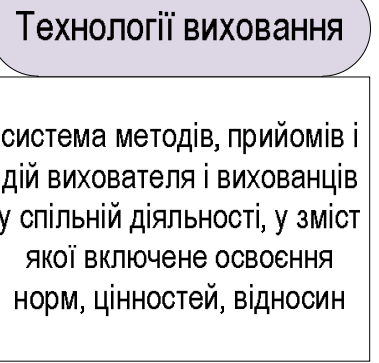

Навчальні технології

інформаційні технології, які можна використовувати для організації процесу навчання

При цьому зміст аспекту «педагогічна технологія» можна розкрити, як наведено на рис. 3.

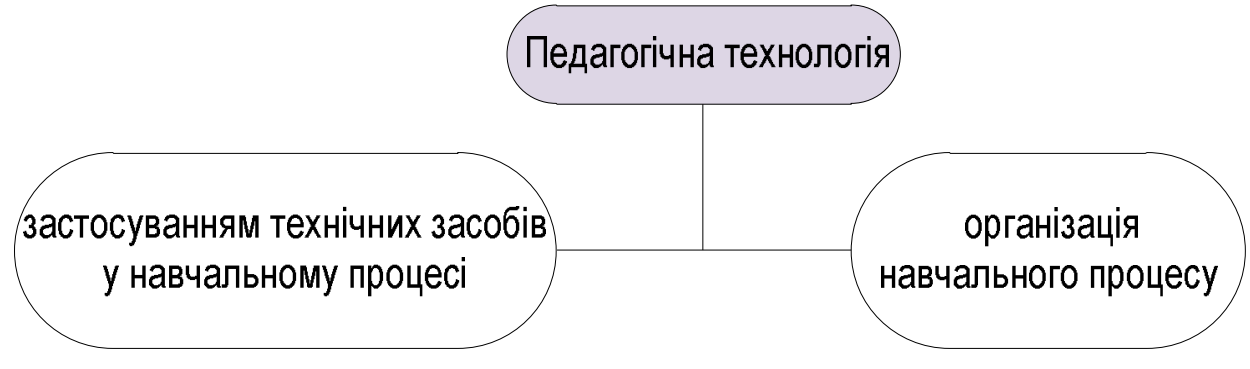

Рис. 3. Зміст педагогічної технології

Вибір освітньої технології залежить від стилю роботи викладача зі студентами, від вибраної стратегії навчання, тактики навчання, його пріоритетів. Всі педагогічні технології ґрунтуються на принципах функціонування системи «педагог-середовище-учінь» [2]

Сьогодні перед викладачами постає проблема вибору необхідних навчальних технологій для досягнення позитивного навчального результату. 
Для забезпечення навчального процесу, орієнтованого на розвиток особистості студента, його творчих здібностей, становлення його морального, фрізичного здоров'я насамперед слід використовувати особистісно-орієнтований підхід (ООП).

ООП полягає в організації освітній процесу таким чином, щоб педагог і середовище поєдналися у єдиному процесі, який допомагає, підтримує, захищає студента, і готує його до життєвої творчості.

Головні завдання ООП наведені на рис. 4.

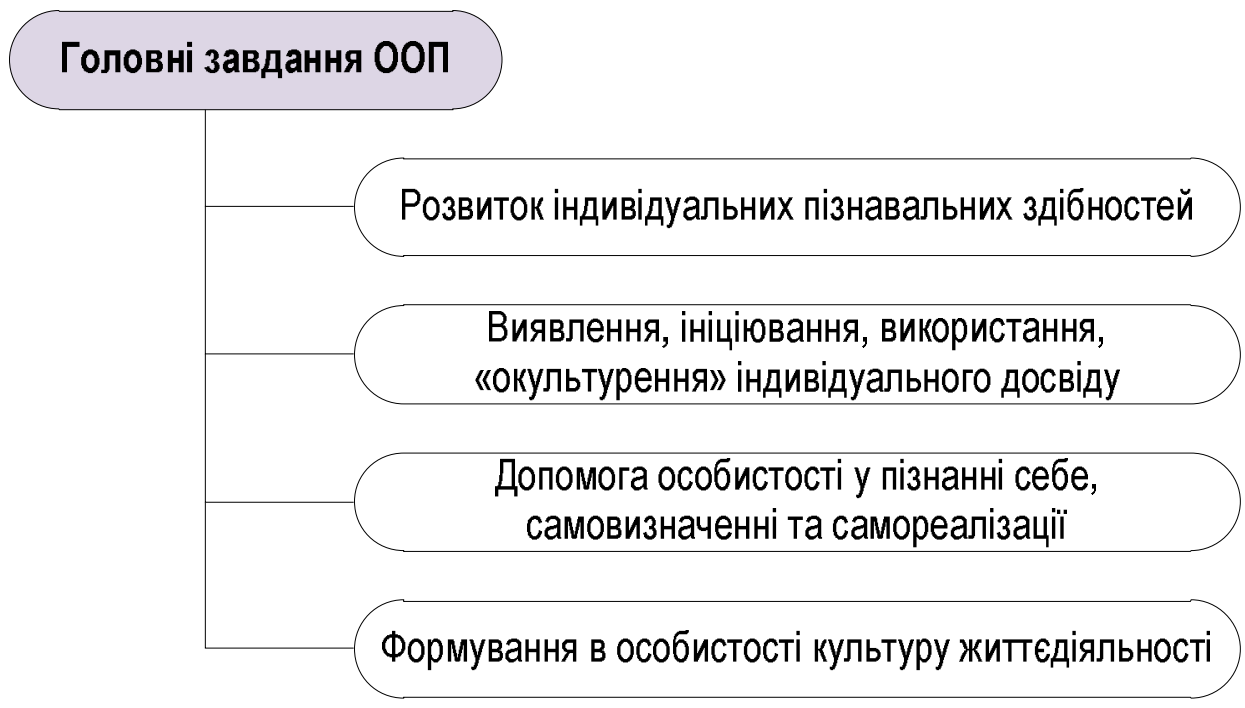

Рис. 4. Завдання ООП

ООП складається з особистісно-орієнтованих педагогічних ситуацій (ООПС). Під ООПС ми розуміємо таку ситуацію, потрапивши до якої студент повинен:

* розуміти зміст цієї ситуації;

- бути зданим пристосовувати до своїх інтересів;

* побудувати образ, модель з точки зору свого життя;

* критично оцінити таку ситуацію;

* вибрати творчий момент з неї.

На сьогоднішній день існує ланка особистісно-орієнтованих технологій (ООТ), але загальноприйнята класифрікація ще не сформулювала, виділяють дві основні школи $[6,7]$ (рис. 5).

Вальддорфська школа

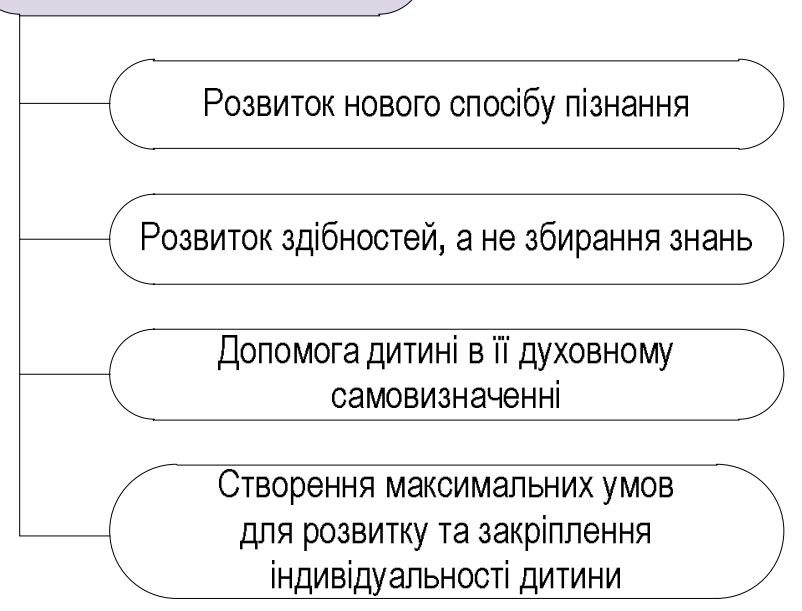

Школа Марії Монтессорі

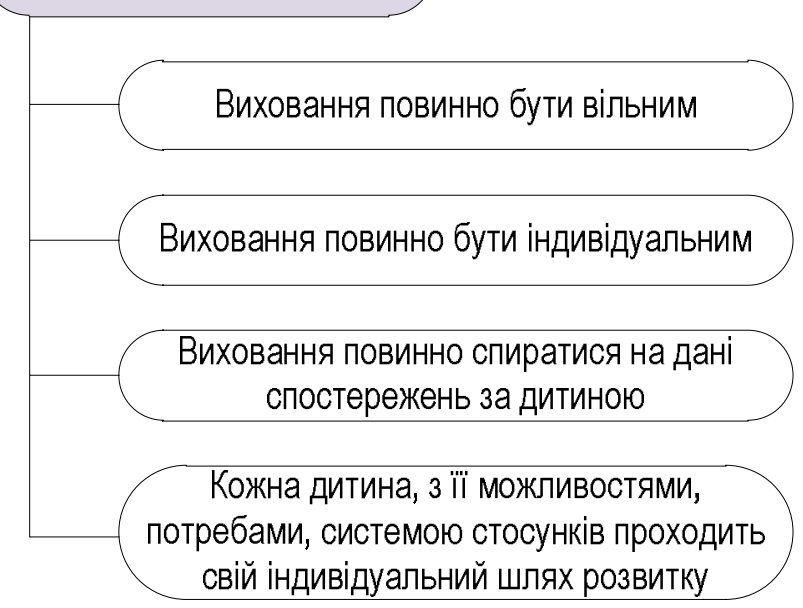

Рис. 5. Основні школи ООТ 
Ідеї М. Монтессорі про взаємовідносини вчителя з учнем виявляють безсумнівний інтерес сучасної педагогічної теорії та практики і мають бути використані у дитячих садках, загальноосвітніх школах, ліцеях та гімназіях [7].

\section{III Результати}

При викладанні математики в коледжі постає потреба до використання таких технологій, які $є$ альтернативними існуючим традиційним формам навчання. Спираючись на дослідження проведені психологами та учителями-методистами приходимо до того, що підвищити активність студентів та ефективність навчання можна використовуючи технології навчання, наведені на рис. 6.

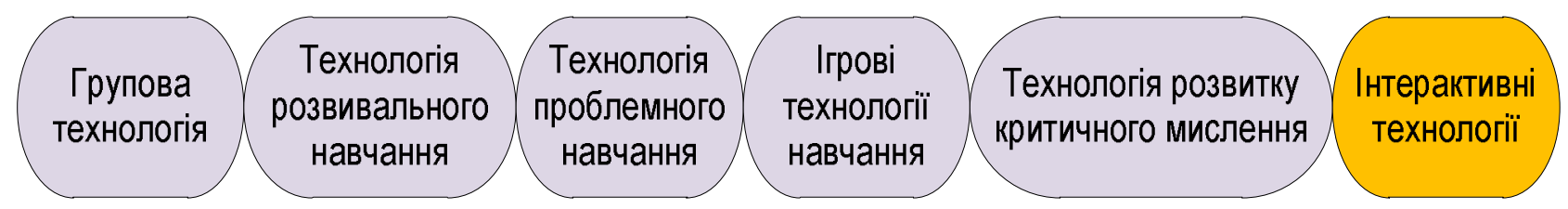

Рис. 6. Використовувані технології навчання

Можна впевнено стверджувати, що пізнавальний інтерес при груповій формі діяльності розширює сферу виявлення вже сфрормованих інтересів учнів, сприяє виникненню нових захоплень, створює умови для більш повної реалізації особистості через обмін зацікавленістю [8].

Функції групової роботи, наведені на рис. 7, форми - на рис. 8.

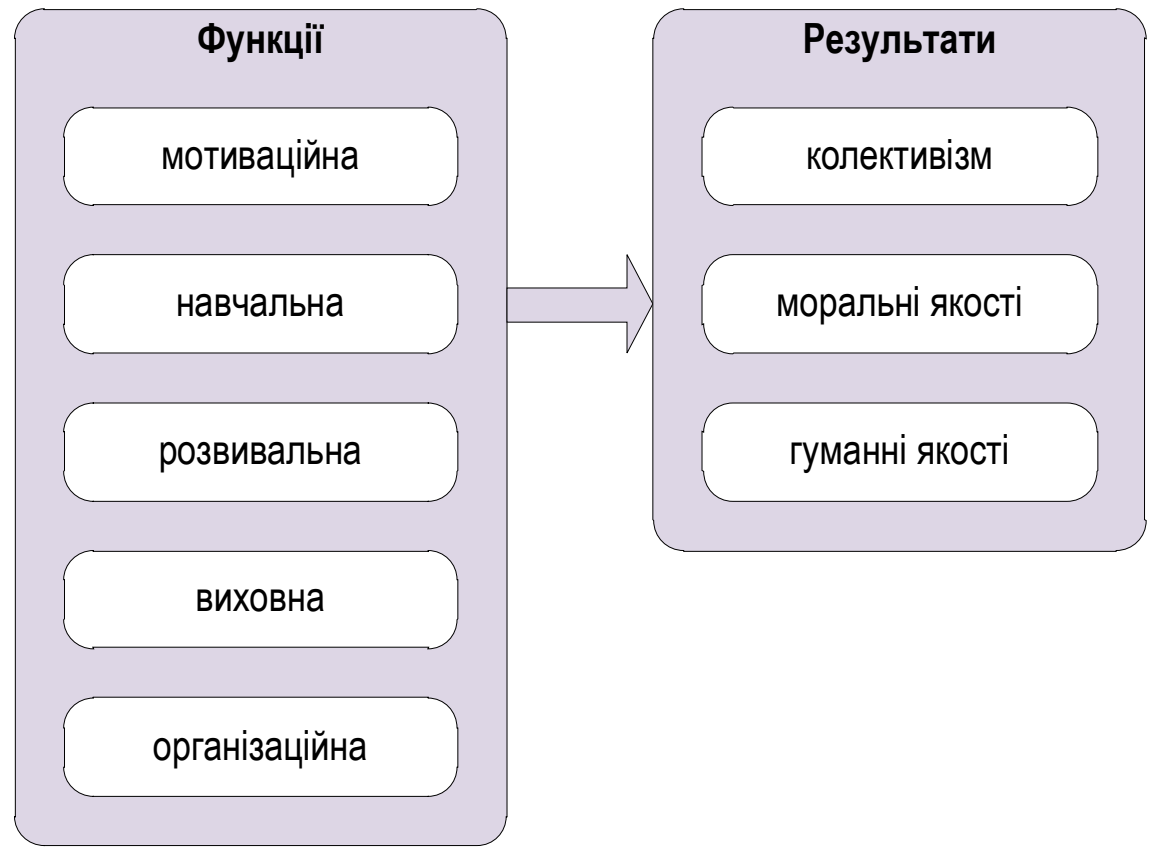

Рис. 7. Функції групової роботи

При використання групової технології можливо виконати більший обсяг роботи за визначений проміжок часу.

Переваги використання групової технології наступні:

* на визначеному етапі заняття підвищується результативність у засвоєнні знань;

* на визначеному етапі заняття краще формуються вміння;

* розвиток здатності до співпраці;

* розвиток здатності до рефрлексії, самоконтролю, взаємоконтролю. 


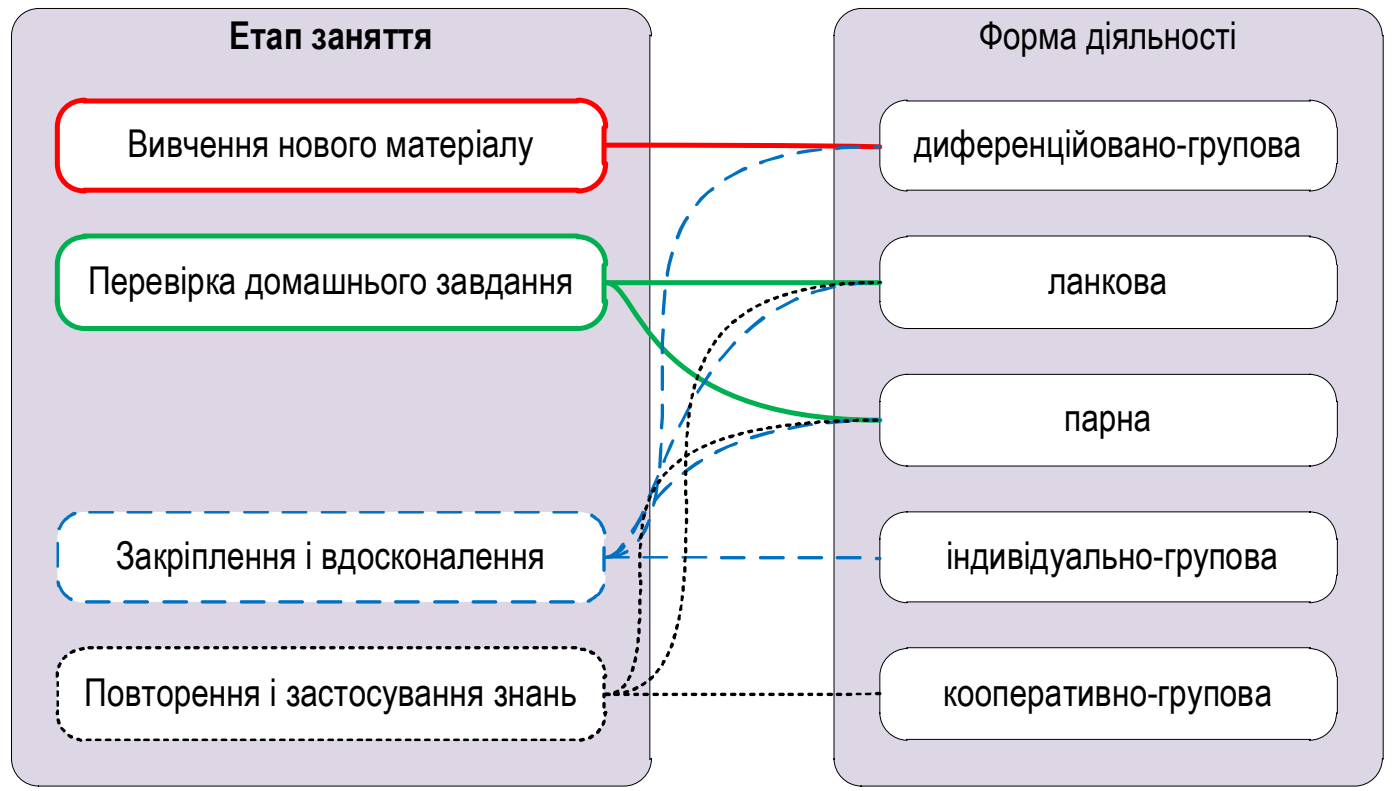

Рис. 8. Використання форм групової роботи на різних етапах заняття

За результатами аналізу проведених досліджень під час викладання навчального матеріалу 3 математики у початкових курсів Н3 другої рівня встановлено, що з ООТ ефективною є технологія розвивального навчання (TPH). Дана технологія досконало вивчена для учнів молодших класів, але необґрунтовано відкидається у старшій школі і безперечно може бути використана для формування навченості студентів коледжу, особливо першого курсу. ТРН ґрунтується на уявленні про розвиток студента, як суб'єкта особистої діяльності. Розвивальне навчання - основа фоормування самостійної, а в подальшому - творчої особистості. Вимоги до побудови заняття згідно з ТРН наведені на рис. 9.

Формування мотивів навчання, позитивного ставлення до нього.
$\begin{gathered}\text { Мотивація навчальної діяльності зацікавлює до вивчення теми спонукає отримання нової } \\ \text { інфрормація для вирішення певних завдань. }\end{gathered}$

Етап 2 Оволодіння новою інформацією, що являє собою пізнавальну діяльність студентів, спрямовану на опанування нових знань та способів навчальних дій.
Відтворення засвоєного матеріалу, це вміння пояснити матеріал самостійно, без опори на будь-
Етап 3 яку підказку, а також застосування його в типовій, звичайній, тобто подібній до навчальної ситуації. Тобто засвоєння матеріалу на самому нижчому, на репродуктивному рівні.

Етап 4 Формування вмінь та навичок у стандартних і нових умовах.

Етап 5

Етап 6
Узагальнення знань, умінь та навичок.

Продуктивна пізнавальна діяльність студентів для фрормування знань, умінь та навичок на творчому рівні.

Згідно з [9] «розвивальне навчання - такий процес діяльності, у ході якого кожен студент повинен самостійно або за допомогою викладача осмислити матеріал, творчо застосувати його в нестандартних умовах та свідомо запам'ятати для подальшого навчання». Модель розвивального навчання розрахована на вдосконалення розумових процесів з урахуванням можливостей кожної дитини. 
Головна мета ТРН - формування самостійного, творчого, активного мислення у студента, і поступовий перехід до самостійного навчання. Завданням ТРН $€$ формування особистості з гнучким розумом, розвиненими потребами до дальшого пізнання та самостійних дій, певними навичками та творчими здібностями. Головною метою викладача $є$ створення таких умов, щоб кожен студент зумів досягти успіху та вірив у свої власні сили. Завдання наставника дати відчути радість від здолання труднощів, зрозуміти, що задарма в житті нічого не дається, скрізь необхідно прикласти зусилля.

Автором технології вважають російського педагога А. Бєлкіна [10]. (TחH).

Дієвою технологією саме у викладанні точних дисциплін $€$ технологія проблемного навчання

Згідно 3 [11] метою ТПН є забезпечення активного ставлення студентів до оволодіння знаннями, уміннями і навичками, інтенсивного розвитку їхньої самостійної пізнавальної діяльності та індивідуальних творчих здібностей, розв'язування навчальних завдань за допомогою не до кінця визначених пізнавальних.

Характерна риса проблемного навчання - постановка перед студентами проблемного завдання, яке створює проблемну ситуацію [12]. В основі ТПН - розвиток викладачем самостійної пошукової діяльності студента із розв'язання навчальних проблем, у ході якої формується нове знання, уміння, навички та розвиваються здібності, активність, зацікавленість, ерудиція, творче мислення та інші особисто значущі якості.

Вміле створення проблемної ситуації, створення протиріччя, стимулює студента до потреби розв'язувати ї̈. Переваги та недоліки проблемного навчання, згідно з [13] наведені на рис. 10.
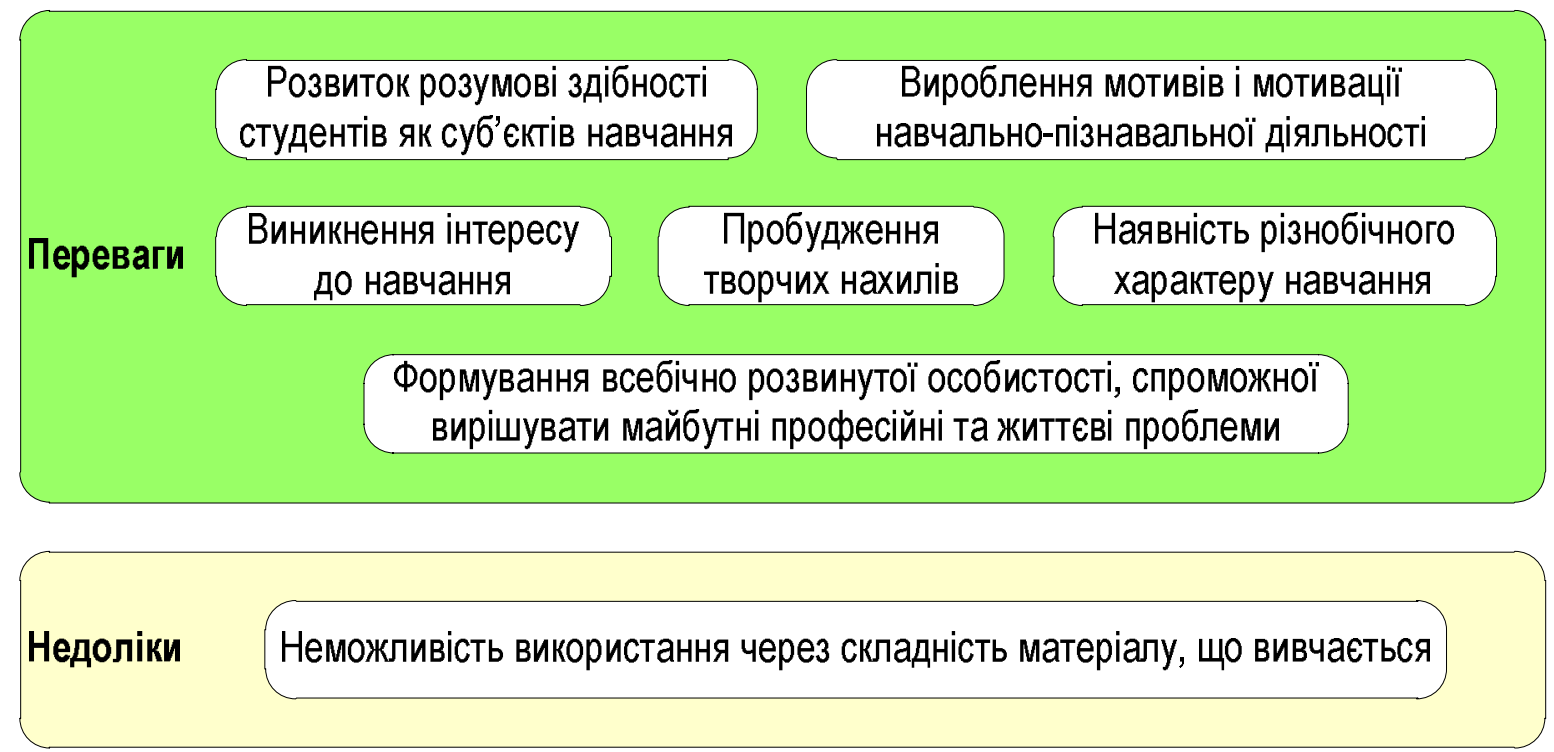

Рис. 10. Переваги та недоліки проблемного навчання

Питання, які можуть бути сфрормовані викладачем, мають викликати інтелектуальні труднощі студентів, направленні на їх розумовий пошук. Висновок повинен спиратися на висновки, які зроблять студенти [13].

Важливою частиною навчальної діяльності $€$ мотиваційний аспект. Для мотивації студентів, зацікавленні їх до вивчення предмету, створення позитивно ставлення до навчання в цілому у своїй діяльності використовую ігрові технології навчання (ITH).

Згідно з [16] можна з впевненістю стверджувати, що гра ефективний засіб активізації, вона мотиваційна за своєю діяльністю, дозволяє вирішувати питання передачі знань, умінь, навичок, багатофункціональна, її вплив на студента неможливо обмежити одним аспектом.

За аналізом результатів застосування ігрових технологій складністю, $є$ те, що для організації гри на занятті необхідна висока обізнаність студентів в темі матеріалу, що розглядається. Якщо студенти мають різні рівні знань та умінь, неякісну підготовку, то організувати їх у гру і задіяти всю аудиторію буде практично неможливо. Тому на заняттях з математики краще використовувати ігрові ситуації, які 
дозволяють підвищити інтерес студентів до предмету, роблять заняття різноманітними, більш цікавими, підвищують активність, навіть пасивних студентів.

Розвиток математичного мислення, аналізу математичних зв'язків, логічних висновків, припущень, можливих наслідків тощо, неможливо, без розвитку критичного мислення студента.

Технологія розвитку критичного мислення (ТРКМ) формує творче мислення, сприяє розвитку креативності, і $є$ однією з найефективніших технологій навчання математики.

Згідно з роботами М. Ліпмана [17] можна виділити 6 ключових елементів критичного мислення, які наведені на рисунку 11.

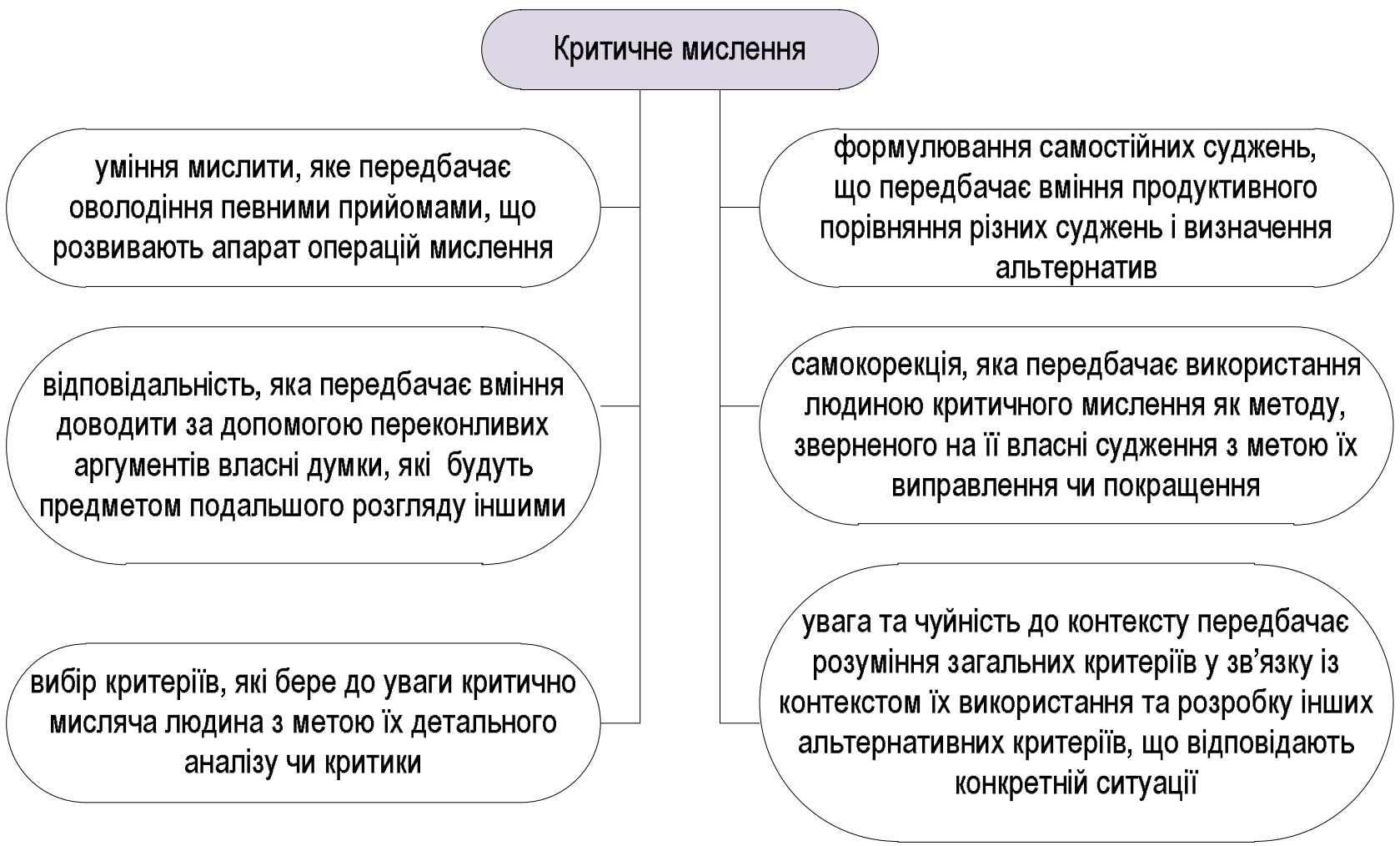

Рис. 11. Ключові елементи критичного мислення

В своїй практичній діяльності для розвитку критичного мислення в математиці ми керуемося такими принципами :

* у навчання включаємо завдання на доведення, розв'язання яких потребує мислення вищого рівня;

- навчальний процес намагаємось організовувати як дослідження студентами певної теми, використовую при цьому інтерактивні методи навчання;

* результатом навчання $€$ вироблення власних суджень, що формуються під час виконання певної системи завдань, яка активізує мислення студента;

* навчаємо працювати зі схемами, таблицями та граффіками, прочитувати різні математичні формули, розвиваю уміння їх застосовувати при розв'язанні задач більш складного рівня;

* мотивуємо до обговорення проблем, що виникають в процесі рішення задач, розвиваю вміння прийти до кінцевого результату, спонукаю не уникати складнощів розв'язання, а переборювати їх.

3 аналізу проведених досліджень під час викладання теоретичного матеріалу, встановлено, що найважливішою умовою критичного мислення є здатність до співпраці, оскільки вона підтримує діалог, спільну мету та взаємне вивчення цінностей. Щоб досягти спільного консенсусу, студенти повинні вміти працювати колективно, захопитися спільною ідеєю для пошуку істини. Викладач виступає в ролі головного генератора, надихає всіх на взаємну підтримку i $€$ більше партнером налаштованим на співпрацю. 
На теперішній час вже неможливо викладати предмети традиційно: у центрі навчального процесу знаходиться викладач, студенти слухають пояснення, виконують завдання. Введення інтерактивних методик дає можливість докорінно змінити ставлення до об'єкта навчання [18].

Реалізація інтерактивного навчання потребує створення наступних умов:

* багатосторонній тип комунікації, що відтворюється в навчальному процесі;

* сприятлива, позитивна психологічна атмосфера в аудиторії під час заняття;

* норми спільної праці, що виробляються разом;

* спеціальне розташування меблів;

обладнання навчальної аудиторії й різноманітні матеріали, що можуть використовуватися під час занять.

Згідно з [18] залежно від мети та форми організації навчальної діяльності інтерактивні технології можна розподілити на групи, наведені на рисунку 12.

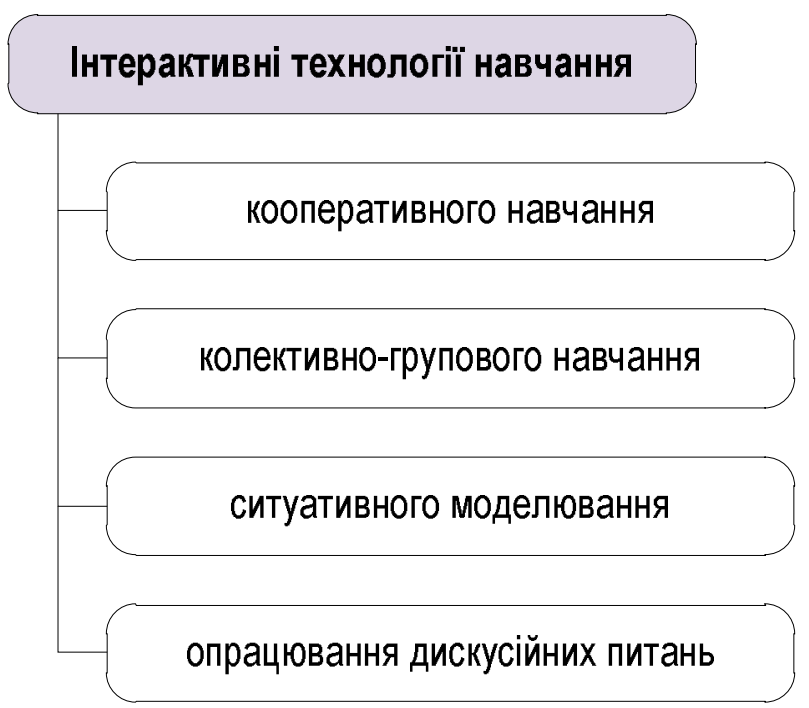

Рис. 12. Розподіл інтерактивних технологій навчання на групи

На заняттях ми, частіше використовуємо парну або колективно-групову роботу, це може відбуватися на початку нового заняття замість опитування, одразу ж після викладання нового матеріалу для формування первинних умінь та навичок, для перевірки знань студентів.

Серед інтерактивних методів навчання традиційно використовую метод розв'язання проблеми, коли всі учасники розмірковують над однією проблемою, так званий «мозковий штурм». Мозковий штурм дозволяє отримати кілька варіантів розв'язання конкретної проблеми.

Технологія навчання у дискусії $€$ важливим засобом пізнавальної діяльності у процесі навчання. В дидактиці дехто з фрахівців відносить дискусію як до методів навчання (способів роботи зі змістом навчального матеріалу), так і до фрорм організації навчання. При чому слід відзначити деякі важливі моменти організації дискусії, наведені на рисунку 13.

Запорукою успішності дискусії є організація, згідно з факторами, наведеними на рисунку 14.

Відповідно до рекомендацій, викладених у [18] студентам можна запропонувати наступні правила:

* говоріть по черзі, а не всі одночасно;

* не перебивайте того, хто говорить;

к критикуйте ідеї, а не особу, що їх висловила;

* поважайте всі висловлені думки (точки зору);

* не смійтеся, коли хтось говорить, за винятком, якщо хтось жартує;

* не змінюйте тему дискусії;

* намагайтесь заохочувати до участі в дискусії інших.

Метод дискусії навчає студентів висловлювати свої математичні ідеї спираючись тільки на закони математики, що обумовлює розвиток критичного мислення, вміння чітко сфрормулювати проблему та визначити шляхи ії розв'язання. Також даний метод сприяє розвитку самостійного навчання студентів. 


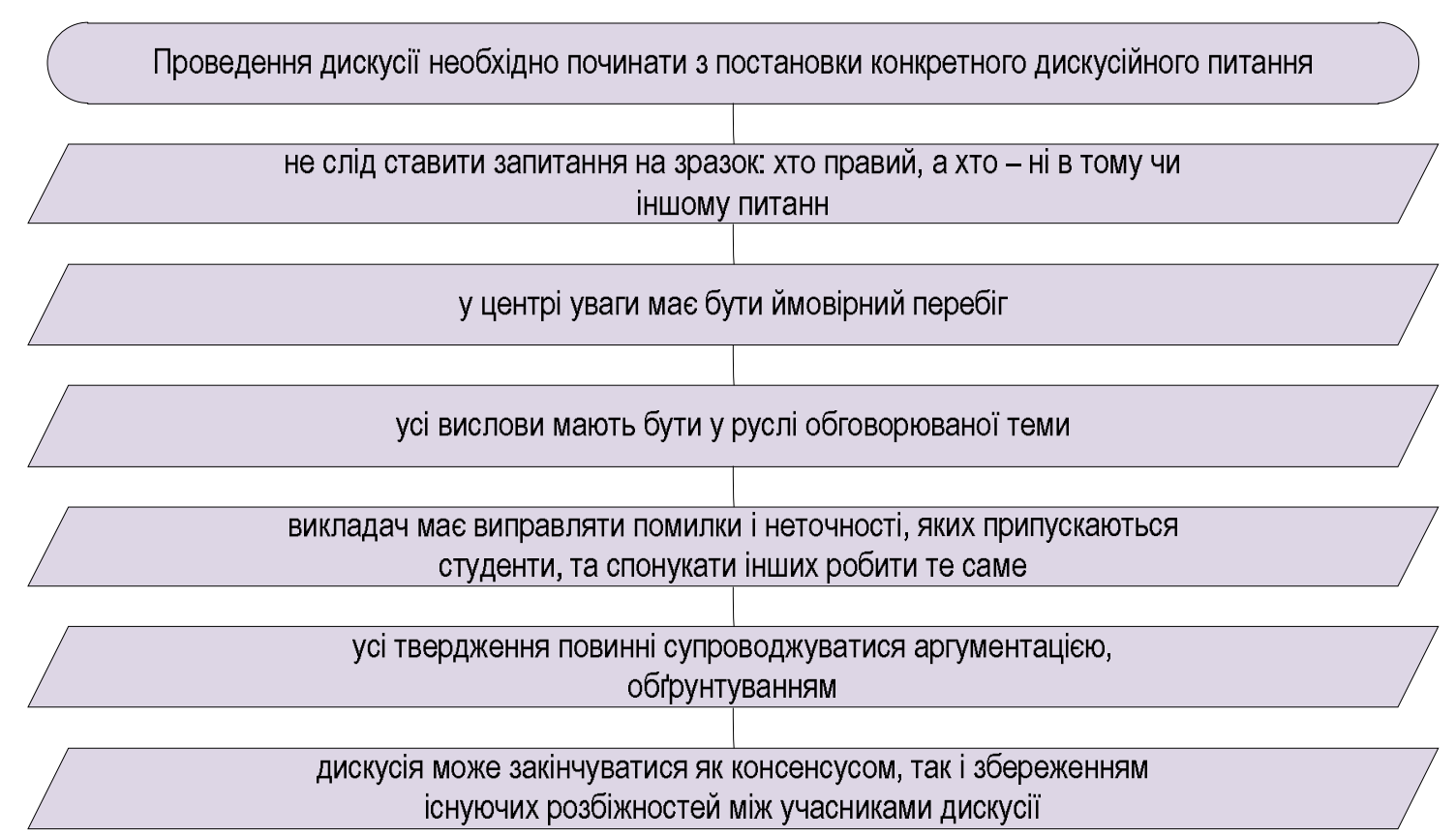

Рис. 13. Організація дискусії

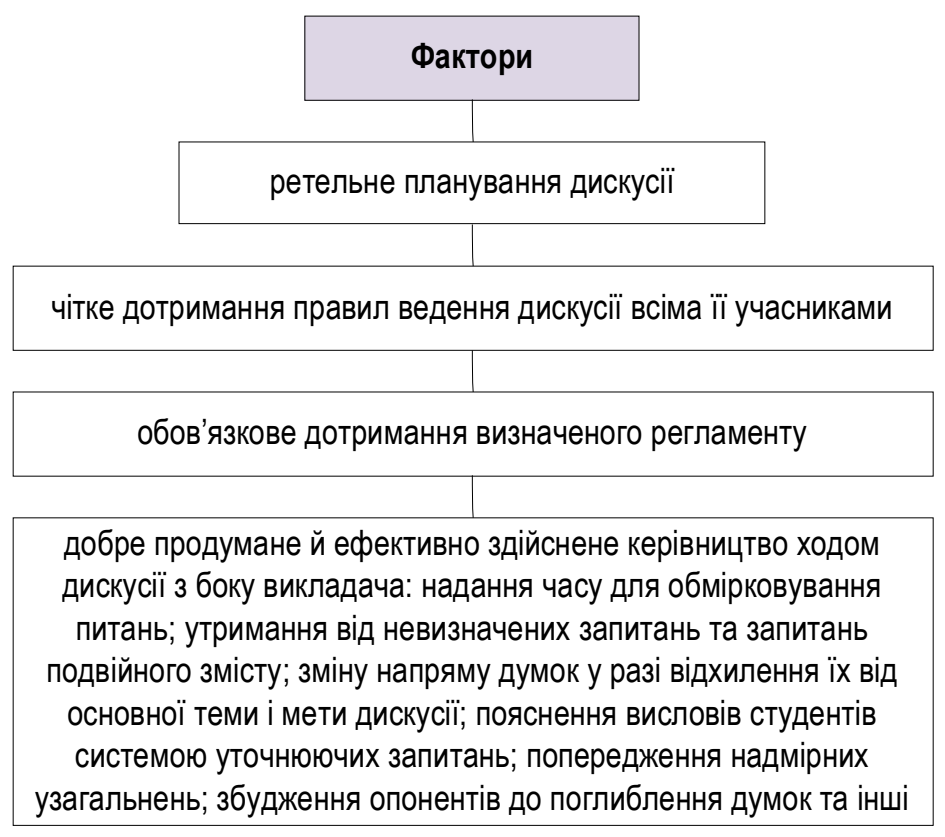

Рис. 14. Фактори успішності дискусії

Проблемою у використанні даного методу може стати недостатня обізнаність 3 теми, що вивчається, бо для пошуку відповіді необхідна певна база знань. Тому без усвідомленого підходу студентів до навчання даний метод можна застосувати тільки частково, на окремих етапах заняття, для мотивації до вивчення тем.

\section{IV Обговорення}

Проблеми, які виникають при вивченні математики у ВНЗ другого рівня та основні завдання у формуванні математичних компетенцій спонукають до оновлення методів та прийомів навчання. Запровадження в навчально-виховний процес різних технологій, сучасних концепцій та способів формування у студентів предметних та життєвих компетенцій $є$ запорукою досягнення позитивного результату в навчанні. 
Застосування інноваційних технологій є результатом творчого підходу викладача до справи. Важливою умовою організації навчально-виховного процесу $є$ вибір раціональної системи методів і прийомів активного навчання, використання сучасних технологій у поєднанні з традиційними засобами.

Для формування математичних компетенцій процес навчання треба організувати так, щоб зорієнтувати студента на досягнення поставлених цілей. Юнацтво повинно прагнути не знати якомога більше, а знати, які знання їм потрібні та вміти їх застосовувати.

Вивчення точних дисциплін це складний та кропіткий процес, який базується на систематичному навчанні. Розуміння студентами практичних завдань та вміння застосовувати математичний апарат до розв'язання професійних здач е основна мета при вивчені математики та вищої математики.

\section{V Висновки}

У реаліях тенденцій розвитку освіти в Україні використання особистісно-орієнтованих технологій в процесі вивчення дисциплін стає нагальною потребою для будь-якого викладача. Особливо це стосується викладачів математичних дисциплін, оскільки відома проблема недостатньої підготовки 3 математики більшої кількості випускників шкіл. Наведені результати розробки методики застосування особистісно-орієнтованих технологій і власний досвід їх імплементації в процес навчання доводять:

* покращення засвоєння матеріалу студентами;

* активізацію творчих здібностей студентів;

* необхідність забезпечення викладача часом та матеріальними ресурсами для впровадження особистісно-орієнтованих технологій;

Питання кількісної оцінки впливу застосування особистісно-орієнтованих технологій на результати навчання являється темою для окремих досліджень.

\section{Бібліографічні посилання}

1. Сафонова І. Я. Розвиток математичної компетентності у старшокласників як шлях до формування всебічно розвиненої особистості. Науковий вісник мну імені В. О. Сухомлинського. 2015. №1(114). С. 237-240

2. Глобін О. І. Критерії та показники результативності компетентісно орієнованого навчання математики в школі. "ITM плюс -2015", Суми: 2001. №2. С. 36-40

3. Глобін О. І., Бурда М. І., Васильєва Д. В., Волошена В. В., Вашуленко О. П., Мацько Н. Д., Хмара Т. М. Компетентнісно орієнтована методика навчання математики в основній школі: метод. посібник. Київ: Педагогічна думка, 2015. 245 с.

4. Кошечко Н. Технології викладання та навчання у вищій школі. Педагогіка. 2015. №1. С. 35.

5. Бараболя М.М., Матяш О.І. Педагогічний довідник вчителя математики. Посібник для самоосвіти вчителів математики. Вінниця: 2010. С.128

6. Вальдорфрська педагогіка. URL: http://zakinppo.org.ua/onlajndovidnik-klasnogo-kerivnika/vihovni-tehnologii-ta-formiroboti/1254-valdorfska-pedagogika (дата звернення 25.08.2019)

7. Павленко В. В. Методи виховання Марії Монтессорі. Методичні засади реалізації особистісно орієнтованого виховного процесу в сучасних освітніх засадах. за редакцією О. О. Максимової, М.А. Федорової. Житомир: 2012. С. 218- 221.

8. Авраменко О. В., Лутченко Л. І., Ретунська В. В., Ріжняк Р. Я., Шлянчак С. О. Інноваційні та сучасні педагогічні технології навчання математики. Кіровоград: 2009. 200 C.

9. Аніщенко О. В., Яковець Н. І., Сучасні педагогічні технологї: курс лекцій. навч. посібник. За заг. ред. Н.І. Яковець. Ніжин: Видавництво НДУ ім. М. Гоголя, 2007. 199 с.

10. Белкин А. С. Ситуация успеха. Как ее создать? Москва: "Просвещение", 1991. 169 с.

11. Пометун О. І., Пироженко Л. В. за ред., О. І. Пометун. Сучасний урок. Інтерактивні технології навчання. науковометодичний посібник. Київ: Видавництво А. С. 2004. 192с.

12. Гончаренко С. У. Український педагогічний словник. Київ: Либідь. 1997. 376 с.

13. Андрєєва В. М., Григораш В. В. Настільна книга педагога. Харьків: Основа, 2006, 352 с.

14. Державний стандарт базової і повної середньої освіти.

15. Юркович В. Г. Наукові публікації. Педегогічний пошук. №3 (91), 2016.

16. Арестенко В. Роль ігрових технологій у підготовці майбутніх учителів природничих дисциплін до професійної діяльності. Збірник наукових праць. №3 (10), 2017.

17. Козира В. М. Технологія розвитку критичного мислення у навчальному процесі: навчально-методичний посібник для вчителів. Тернопіль: ТОКІППО, 2017. 60 с.

18. Пометун О. І., Побірченко Н. С., Коберник Г. І., Комар О. А., Торчинська Т. А. Інтерактивні технології: теорія та методика. Посібник для викладачів ПТУ, коледжів та всіх тих, хто цікавиться застосуванням інтерактивних технологій у навчальному процесі задля його вдосконалення. Умань-Київ: 2008. 94 с. 


\section{References}

1. Safonova, I. Ya. (2015). Development of mathematical competence in high school students as a way to form a comprehensively developed personality. Scientific Bulletin of VO Sukhomlinsky, 1 (114), 237-240.

2. Globin, O. I. (2015). Criteria and performance indicators of competently oriented mathematics teaching at school. «ITM plus 2015», 2, 36-40.

3. Globin, O. I., Burda, M. I., Vasilyeva, D. V., Voloshena, V. V., Vashulenko, O. P., Matsko, N. D., Khmara, T. M. (2015). Competently oriented methodology of teaching mathematics in the basic school: method. manual. Pedagogical Thought, Kyiv, $245 \mathrm{p}$.

4. Koshechko, N. (2015). Technologies of teaching and learning in higher education. Pedagogy, 1, 35.

5. Barabola, M. M., Matyash. O. I. (2010). Teacher's guide of mathematics teacher. A guide for the self-education of mathematics teachers. Vinnytsia, $128 \mathrm{p}$.

6. Waldorf Pedagogy. URL: http://zakinppo.org.ua/onlajndovidnik-klasnogo-kerivnika/vihovni-tehnologii-ta-formi-roboti/1254valdorfska-pedagogika (accessed 25.08.2019)

7. Pavlenko, V. V. (2012). Methods of education of Maria Montessori. Methodical principles of realization of personally oriented educational process in modern educational principles. Zhytomyr, 218-221.

8. Avramenko, O. V., Lutchenko, L. I., Retunska, V. V., Rizhnyak, R. Ya., Shlyanchak, S. O. (2009). Innovative and modern pedagogical technologies of teaching mathematics. Kirovograd, $200 \mathrm{p}$.

9. Anishchenko, O. V., Yakovets, N. I. (2007). Modern pedagogical technologies: a lecture course. teach. manual. For the title. ed. NO. Jacob. Publishing house of NDU them, Nizhyn, $199 \mathrm{p}$.

10. Belkin, A. S. (1991). The situation of success. How to create it? "Enlightenment", Moscow, 169 p.

11. Pometun, O. I., Pyrozhenko, L. V. (Ed.), Pometun, O. I. (2004). Modern lesson. Interactive learning technologies. scientific and methodological manual. AS Publishing House, Kiev, $192 \mathrm{p}$.

12. Goncharenko, S. (1997). Ukrainian Pedagogical Dictionary. Libid, Kiev, 376 p.

13. Andreeva, V. M., Grigorash, V. V. (2006). Pedagogical book of the teacher. The Basis, Kharkiv, 352 p.

14. State standard of basic and complete secondary education.

15. Yurkovich, V. G. (2016). Scientific publications. Pedagogical search, 3 (91).

16. Arestenko, V. (2017). The role of game technologies in the preparation of future teachers of natural sciences for professional activity. Collection of scientific works, $3(10)$.

17. Kozira, V. M. (2017). Technology of the development of critical thinking in the educational process: a teaching manual for teachers. TOKIPPO, Ternopil, $60 \mathrm{p}$.

18. Pometun, O. I., Pobirchenko, N. S., Kobernik, G. I., Komar, O. A., Torchinska, T. A. (2008). Interactive technologies: theory and methodology. A guide for VET teachers, colleges, and anyone interested in using interactive technology in the learning process to improve it. Uman-Kyiv, $94 \mathrm{p}$.

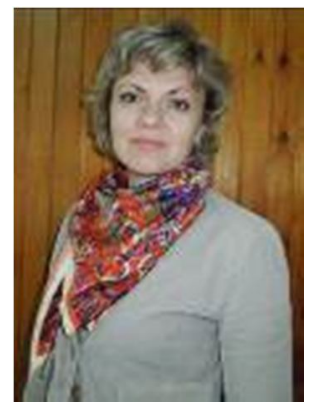

\section{Туманова Наталія Павлівна.}

Викладач математики, кваліфікаційна категорія «спеціаліст вищої категорії»,

Світловодський політехнічний коледж Центральноукраїнського національного технічного

університету.

вул. Городоцька, 15, м. Світловодськ, Україна, 27501.

E-mail: natalaiya.tumanova.76@mail.com

\section{Tumanova Nataliia Pavlivna,}

Teacher of Mathematics, Qualification Category "Specialist Of The Highest Category",

Svitlovodsk Polytechnic College of the Central National Technical University,

vul. Horodotska, 15, Svitlovodsk, Ukraine, 27501.

E-mail: natalaiya.tumanova.76@mail.com

\section{Citation (APA):}

Tumanova N. (2019). The use of personally-oriented educational technologies in the formation of mathematical competences.

Engineering and Educational Technologies, 7 (4), 31-43. doi: https://doi.org/10.30929/2307-9770.2019.07.04.03

\section{Цитування (ДСТУ 8302:2015):}

Туманова Н. П. Використання особистісно-орієнтованих освітніх технологій у формуванні математичних компетенцій $/$ Інженерні та освітні технологіï. 2019. Т. 7. № 4. С. 31-43. doi: https://doi.org/10.30929/2307-9770.2019.07.04.03

Обсяг статmі: $\quad$ сторінок - 13 ; умовних друк. аркушів - 1,883. 